\title{
Embodied Souls, or Ensouled Bodies: A Critical Analysis
}

Willie Cox

\begin{abstract}
Gender isn't a concept of being black and white or male and female. Times are hanging, and Americans no longer assume that everyone should fit into binary male or female categories. Globally, gender is determined by our genes and to be male or female is instilled in our nature, hence it is not just related to cultural indoctrination. Souls don't have a gender; they are the invisible sex. Life is made for us to face the challenges of human nature which have a certain control on our behavior, irrespective of the soul men perceive in a different way and women in a different way. Souls have no genitals, and certainly do not reproduce, thus they have no gender. Humans are more than just a body, the body is controlled by consciousness interconnected with the brain, denoting we have a soul. All the souls are made up of the same essence and substance but are verily distributed between individuals. We are not embodied souls, but ensouled bodies! This paper will focus on the belief of immortality and the arrival and presence of the soul and what happens to the gendered essence (the soul) when we die?
\end{abstract}

Keywords: Cultural indoctrination, Ensouled bodies, Gender, Embodied souls

\section{Introduction}

Our souls have no gender. Human beings are not mechanical devices that could be mutated at will. ${ }^{1}$ They are a reality deploring the ancient unorthodoxy of Gnosticism. It is (Gnosticism) the belief that asserts that humans are divine souls imprisoned in the regular physical or material world, conveying the idea that the 'real' self (body), is separate from the embodied soul. This is a living truth since Adams regardless of the downturn in the global economy. We humans are not embodied souls, but ensouled bodies! what matters the most is who we are as human beings. Ascertained by the National Catholic Bioethics

${ }^{*}$ Professor Willie Cox, 2712 Center Ave Richmond CA, United States 
Center, a think-tank on concerns related to religion corroborated, "A human being is the union of soul and body, and the soul should not be discerned as an insignificant self, but it is the body that carries the soul and is termed as a human person. Without either of these none can exist. ${ }^{2}$

"Gender" received recognition in the late 1960's and early 70's and ever since has been spreading like an intercontinental ballistic missile. It was a time when the concept of feminism was becoming rampant as a logical and serious matter amongst the people and societies. Until this time, the term "sex roles" was used to address all notions associated with the anticipated concepts of masculinity and femininity. The term "Gender" was presented by a group of feminist intellectuals as a counter-discourse for the executed-discourse of "sex roles" in the patriarchal (male-controlled) societies of that time. As stated earlier, in view of these feminists, that natural differences between a man and a woman that effect the mental, behavioral and cognitive differences, are deeply rooted under the dominion of patriarchal culture. ${ }^{3}$ Subsequently, families found it most significant in reproducing the male gender discriminations and perpetuating patriarchy. ${ }^{4}$

Besides, the relationship between the soul and the body is similar to the dependent issue of man and woman. According to the Performative Acts and Gender Constitution masculinity and femininity are described as one group and not as separate species. ${ }^{5}$ Masculinity and femininity are observed to have characteristics of animals. It is the division of the first rank of the animals from plants. Therefore, gender cannot be misunderstood with any of the species or the soul. ${ }^{6}$ The Reality of the Soul is a notion in the peripatetic school of thought worldwide. Undeniably, there are two elements. One being the truth of the soul as a balancedelement, and the other being the body as a physical element. Consequently, the presence of the soul is extra and separate from the entity of the body. Avicenna, also known as Ibn Sina, the world's famous Persian polymath, observed as one of the most noteworthy physicians, astronomers, thinkers and writers of the Islamic Golden Age, ${ }^{7}$ also commonly known as the father of early modern medicine. Out of his 450 works that he had produced, around 240 have survived till date, 150 of those are on philosophy and rest 40 is on medicine. He described the relationship between the soul and the body as the relationship between a construction structure (building) and the mason (building maker or the builder). ${ }^{8}$ 
According to him the assembly of the soul and the body is as significant and substantial as the building and the mason, but this affiliation is an unintentional relationship. Few critics notice no difference between the presence of the soul and the essence of the soul and is considered as a universal blanket. ${ }^{9}$ Philosophers believe that a soul is perfect when it has an interactive dependence on the body. It is correlative to the relationship of the builder with the building he constructs. The work of art the building displays, gives us an in-depth idea about the builder, even though the building has nothing to do with the builder as the builder is a human and the building is just a structure. In order to justify the entity of the soul, the soul is transferred in a physical container - (the body), body on one hand and a rational substance on the other. Hence, the essence of the soul that is the rational element remains unintentional to the body. ${ }^{10} \mathrm{~A}$ distinct influence comes from the belief that a vegetarian soul, is later or in the next life, transformed into an animal's soul and vice versa. According to the special theoretical contribution it is believed that the concept of the soul does not include two presences or existence, rather only one. Therefore, the existence of the soul is the same as its essence and the truth of the soul is nothing but prudence and superintendence. ${ }^{11}$ On the contrary, the soul is only one spiritual element that cannot be termed as two substances. The soul can also be referred as an abstract but it cannot be analyzed as an accidental happening because the presence of the soul is meticulously affianced with dependence and not forecasted to be associated with accident. The soul is not a dependent element like in the case of the building, the building is, as until the builder continues construction, the building does not get its shape and form. Consequently, instead of the soul, the body is rather a dependent element as until the soul sweeps in the body the body doesn't come to life. Soul being a material form far or close to rational origin, depending on the body's strength or weakness contingent on the existence of the soul. ${ }^{12}$ The soul is an everlasting and forever existing element. It is pre-eternal because of its liberation to live without transubstantiation and alteration. The qualities that the soul carries pre-exist in the soul, resulting in no development or deficiencies or developing new qualities through time. In other words, the vital rightness of the soul's ingredient is the prerequisite of its pre-eternality. But to debate over these ideas briefly, the conclusion drawn would not be true about the soul. As it has been verified that the soul entails mechanisms and potentialities to attain insight and dynamic forces which it lacks from the beginning and to achieve excellence by 
that means. Therefore, the soul's conceptual potentialities and Mechanics could either be vegetative or of animal types and this depicts its Pre-existential deficiency and therefore, casts off the pre-eternality of the soul as an element. ${ }^{13}$

\section{The Philosophical Considerations of Soul}

A proven hypothesis of the existence of the soul by Plato along with some other classical philosophers is that they assume the soul as a truth detached from matter. They accept as true, the soul to be immaterial and an element that exists before the actual body that carries the soul gets its existence, affirming that soul has pre-existed the body as if the soul has been waiting to connect with the body when it is ready and to dwell in it until death does it apart. Towards the end of life when the body is about to fall, as the powers fade away and the organs start to shut down, the soul returns.

Thus, the soul being pre-eternal, is in no way dependent on the body and does not control the body functions. The soul is fundamentally rational and immortal, and the human body serves only as a temporary prison for the soul for as long as the body continues to live. ${ }^{14}$ The soul has always existed in heaven or purgatory and only descends and is confined in a physical body. Till the soul remains in the heavens it observes and acknowledges the truths of the universe; nevertheless, after transition to the other world, on entering earth and merging with the body the soul forgets all the knowledge of the heavens and the memory becomes as blank as a blank sheet of paper. The arrival and presence of the soul in this world is established by two factors, its transformation in the body and the sensory phenomena. These sensory feelings, urge the bodily sensations that herald or escort the repetitive behaviors associated with the soul. ${ }^{15}$ These feelings can only be related to as reflections or recollections from the soul's previous life. Just like a curtain hanging on a mirror to restrict the view, the body also acts as a similar barrier towards light (soul) and reflection of forms (the sight that the body envisions). The human body has been programmed to remember and recollect. ${ }^{16}$

\section{An Appraisal of Mind-Body Relations}

Plato believes that the creator has created the soul in such a way that it exists prior to the body from the time of emergence. This concept also exists to be a universal phenomenon. The soul has an elevated status over the body and presumes to be the master of the body ${ }^{17}$ because factually the soul has always 
existed in the heavens, even before blending within the body. Therefore, the pragmatic approach and perceived truth of the soul is that as it descends to the world for a temporary stay it forgets all the learning that had taken place in the heavenly world. Therefore, what humans learn during their stay in this world is not a new acquaintance but only a slight memory of the forgotten past. ${ }^{18}$ Every entity in this world enjoys a certain level of existence. In the classification of the body and the soul, matter is classified as the lowest level of existence. It is followed by animals, plants, minerals, and finally humans. ${ }^{19}$ These entities are externally diverse, and spiritually united internally. Therefore, the entire universe enjoys a certain level of existence where the human soul exists in the world of supernatural intellect. The concept of pre-eternality of the soul presented by M. Yazdi ${ }^{20}$ has been rejected because of numerous reasons, further discussed. His argument that if the soul has always existed in the celestial world, then there should be a number of souls, it cannot just be one soul, which is evident because one soul cannot be concealed in a number of bodies because the number of people that inhabit the planet earth are uncountable so his argument is justified that for every human there is a soul. He further claims that just like all humans are different from each other, not even one is the exact copy of the other, in the same way the soul is should also be unique because a same soul cannot inhabit everybody's body, thus souls are pre-eternal. Furthermore, he also adds that the souls are made from a different matter than the human bodies. ${ }^{21}$ It is apparent that the souls have diversity; therefore, all the souls are made up of the same essence and substance but are verily distributed between individuals. The matter of fact is that how a soul that is made up of a completely unique essence can be infused in a body that has physical shape and form.

Furthermore, the body holds the soul for as long as it lives, until the soul departs from the body for its eternal journey. ${ }^{22}$ The body has physical form; thus it rots, but the soul being spiritual, takes its next flight. A number of critics like Avicenna and Suhrawardi agree on the origination (emergence) of the soul. Yet many also disagree in the pre-eternality of the souls and the divine and mystical transformation of the emergence of the soul. Peripatetic theorists discard the pre-eternality of the soul. They believe that the birth of a child and the child's body being infused with a soul is a simultaneous process (more related towards a scientific process). They believe that as soon as the process of the creation of the human body is completed, God concurrently creates the abstract soul and unites the two forms by infusing the soul in the physical body because two 
things of different matter and substance cannot merge and unite like oil and water do not mix. Thus, stressing that the soul is not pre-eternal or spiritual, rather it is produced when needed to be infused in a body resulting in the proposition that it is more of a physical essence rather than a spiritual entity. Two different entities that have different form and matter cannot be united as one. The soul cannot be associated with the physical body which is why after the body falls, the existence and presence of the soul also comes to an end. ${ }^{23}$

The soul is not composed of physical form, instead it is an abstract identity that is formed and united with the body once the child is ready to see the lime light and come into this physical world as prearranged by the Lord's command. Avicenna quotes, "When a body is ready to accept the soul, it is united with an abstract, adequate and sublime soul that undergoes all suffering that the body encounters. ${ }^{24}$ The pre-eternality of the soul wholly depends upon the doctrines of principality, substantial motion and analogy of existence. Avicenna, however, rejects the concept of gender based soul. ${ }^{25}$ The soul is an abstract form of presence that is instilled in the human body that has physical form. People far and wide strongly support this concept. Thus, the body having physical potentiality is merged with a spiritual existence which is combination of spiritual and earthly creation as the body takes its form on earth inside the womb. The dependence of the soul on the body is sensual in nature as it accomplishes a relationship of unity. The soul can also be attributed with gender.

However, this issue of gendered soul has been restricted only to few discussions and not based on beliefs largely. According to MesbahYazdi, it is rather very difficult to distinguish between the masculinity and feminity of a soul and the idea seems irrelevant. Since the soul does not have any genital organs, it can neither be distinguished as a male soul nor a female soul, but once it has been merged in a human body, the gender of the body is then the only gender that is considered as a man or a woman rather than separating the gender of the body and the gender of the soul. ${ }^{26}$ It is largely believed that the soul has no gender. Practically every single soul has both genders. Souls have male and female energies. Even though it is found in fluctuating percentages. Souls can relate energetically to each other. ${ }^{27}$ In this way the soul is bisexual and can take either side in an artistic way. This elasticity is a natural phenomenon of the cosmos. If a person expresses this gender through physical sex, every human has the 
capacity to relate to either male energy or female energy. It is common for people to be physically bisexual to some degree in many of their lifetimes.

When a soul dwells in the body of a male body, the principal lessons in that body relate to male energy, and likewise, the soul in a female body carries female energy. If the soul has had frequent transfers in both male and female bodies, ${ }^{28}$ the identity becomes limited to the gender of the body that becomes the dwelling of the soul. In such a case the soul has characteristics of both and carries male as well as female energy. However, in this situation the body can use both your male and female energies as appropriate. Keeping aside satisfying sexual relationships, all the rest are equally managed and balanced by the soul. The human body adopts tendencies apart from the personality the soul lives in. For instance, an elderly body or a forty-five year old person's body has a tendency to feel relaxed and be comfortable with others of about the same age. Nonetheless, the soul in the body might also feel inversely, and invalidate the tendency of the body. For instance, he may have made an agreement on a soul level to mingle with someone who happens to be much older or younger than he is or he might have unresolved issues with an either older or younger partner (because of the transference of the soul in a male or a female body). ${ }^{29}$ Therefore, he is attracted to such partners because of his soul but the body behaves according to its understanding and comfort level. Resulting in the situations when individuals seek gender transformation, there is a clash between the body and the soul and both the mediums are unable to settle with either and thus result in transformation.

Generally, heterosexuality is a setting by default in our bodies for reproduction. Precisely, our sexual alignment is specifically not determined by our soul before our life begins; rather, our disposition instinctively indicates or endorses it at the initial stage of childhood. Yet, the soul can set up the body's (or the individual's) life plan. Reincarnation also influences a body and a soul. The previous life experiences leave an impression on the present life and influences our living. These changes, transformations and experiences strongly effect whether the soul is male or female (gender) ${ }^{30}$ However, the human personality has freedom of will; it habitually sanctions the soul's stimuli, but not always. Orientation is not determined consciously, and cannot be changed later in life by conscious willpower. A gay person cannot decide to be straight, just as a straight person cannot decide to be gay. Those who seem to change based 
on conscious choice are, in fact, bisexual to some degree, although repressing their dominant tendency rarely holds up over the long term.

Many factors can contribute to a person's sexual orientation, depending on a male or a female body. Some souls are in persuasion of same-sexual orientation for internal balance. For example, those who have not been transforming from male bodies and seek to learn about male energy might choose either, to be reborn in bodies of males and with a desire to develop sexual relationships with male counterparts, in a way reflecting on their past experiences. ${ }^{31}$ Similarly, those that had been females more often, and had probably been in close encounters with men sexually, therefore, continuing with the same gender, gives the soul a greater sense of comfort and satisfaction in getting close to the male gender. Even a reversal in this situation is justified. Souls that were heterosexual and were involved in challenging (unloving) relationships might adopt homosexuality in order to learn and improve their previous experiences by having involved in loving relationships with the same sex. ${ }^{32}$ Correspondingly, those souls that were victimized as homosexuals in previous lifetimes may choose homosexuality as a tool to win compassion. One sphere that endures to become an important part of practice these days is our over dominating culture and the taboos that dominate our actions even today. Homosexuality is often a response to a culture's extreme divergence of the masculine and feminine. ${ }^{33}$ It has a tendency to see masculinity and femininity as "either or or," instead of two consistent facets of one thing on a continuum. They are endorsed as extreme, inadequate, and unyielding stereotypes rather than sweeping aspects of human potential. The other abilities of manhood and the more intensive potentials of womanhood are not sufficiently accredited and respected. Those who reveal them are not seen fully acceptable and are not allowed to be who they actually are.

The relationship between the body and the soul is like two different objects with different matter and form that are not similar identities. Thus, the hypothesis stands proved that the soul is a spiritual existence. ${ }^{34}$ All physical beings (human beings) from the moment the journey of the embryo in the womb evolves and ascends through various stages in a specific duration of time goes through various stages of spirituality. The concept of soul is considered as potentiality that can be actualized before it is infused in a body and from there it evolves 
and develops in a unique manner which is different from the physical development of how a human body grows and develops.

During this process of growth and development the human body (along with the soul) experiences two different types of developments. One, physical growth like aging of the body that only stops aging until death bids farewell. The other being an invisible spiritual development that keeps feeding the soul and stirring within the whole existence and it does not end because after the body falls, the soul continues to travel for its next journey leaving the body. ${ }^{35}$ Methodical knowledge is escalating day after day at an increasing pace, and so are the consequences of new expansions globally, those that encounter the contemporary framework vis-à-vis the true nature of authenticity, that have far-reaching effects. One sphere that endures to become an important part of study is the affiliation between the brain, mind, and consciousness.

In the United Kingdom, the prefix "Mx" for gender-neutral is being increasingly used on driver's licenses and bureaucratic forms such as banking statements. Americans, however, have been slower to use Mx in lieu of Mr. or Ms. ${ }^{36}$ Popular culture has started reflecting this shift. In the Showtime series "Billions," Asia Kate Dillon, the self-described non binary actor who identifies as neither male nor female and uses the pronouns "they," "them," and "theirs," plays a non-binary character named Taylor Mason. ${ }^{37}$ Science that leads us to the most practical and moral intelligence towards the fact of life that there exists an outer man an inner man within the human bodies, also referred to as the second man. Technically all humans are made up of two beings; one constitutes of our physical and etheric body that is the peripheral world. Peripheral in a way that these bodies are indicators of the divine Spiritual animations (the soul). Whereas the inner man is correlated to the astral body and ego (the body). Allied with the universe the astral body and ego are younger than the physical and etheric body. The famous book on Occult Science also discloses the facts and mysteries of the methodical study of the concealed laws of man and its relationship with the soul. The physical and the etheric body falls asleep, our soul travels in time (past or future), or the outer universe ${ }^{38}$ However, the ego and astral body undergo experiences within the physical and etheric bodies.

\section{Conclusion}

In conclusion we might assert that the invisible sex (soul) remains in connection with the universe, and with the whole cosmos in both situations, when it was in 
the heavens before it was infused in the human body and also after it is united with the body, the connection of the soul with the cosmos continues. This connection of the soul with the universe or the time the soul takes to travel to and from the earth, till the time of departure from the body, can be expressed with great surprise by the fact that the number of average breaths that we draw in a twenty-four-hour cycle equates to the number of years that the soul takes to return to its destination required for the Vernal Point to return to its original point of departure.

\section{References}

${ }^{1}$ Heath Fogg Davis, https://www.cnn.com/2017/08/01/index.html

2 Edward Furton. "Ethics \& Medics." The Journal of the National Catholic Bioethics Center, ISSN 1532-5490, 2001

${ }^{3}$ Charlotte Witt. The Metaphysics of Gender. New York: OUP USA, 2011.

${ }^{4}$ Rudolph Tanzi. International Journal of Women's Research New York Times, 2017

5 Judith Butler. "Performative Acts and Gender Constitution: An Essay in Phenomenology and Feminist Theory." Theatre Journal 40, no. 4 (1988), 519. doi:10.2307/3207893.

${ }^{6}$ Hadi Sadeqi. "Rationality of Belief in Action: A Look at the Theory of Allamah Tabatabai." Existenz: International journal in philosophy, religion, politics, and the arts 7, no. 1 (2012), 23-45.

7 Jonathan Daly. The Rise of Western Power: A Comparative History of Western Civilization. London: A\&C Black, 2013.

${ }^{8}$ Frank Redmond. Functions of the Soul and Knowledge of the Self - Avicenna, 2005

${ }^{9}$ Tony Warren. Difference between the Soul and Spirit, 2013.

${ }^{10}$ Seyyed Hossein Nasr. Philosophy in the Land of Prophecy. State University of New York Press. 2006

${ }^{11}$ International Journal of Women's Research 3 no. 1, Spring \& Summer 2014.

12 Metaphysik und politik - Joachim Ritter, Baden Publishers, Germany. Suhrkamp. 2003

13 Muhammad T. MesbahYazdi, 2014.

${ }^{14}$ Dave Clark. The concept of an immortal soul, 2016.

15 The Three Worlds, Jazz, Dixieland, Blue Flame Publishers.2010. 
${ }^{16}$ James Fieser. Great Issues in Philosophy. Available at:

http://springerhistory.weebly.com/uploads/2/2/0/7/22079454/great-issues.pdf

${ }^{17}$ Ibid

${ }^{18}$ Michael Groneberg. "Myth and Science around Gender and Sexuality: Eros and the Three Sexes in Plato's Symposium." Diogenes 208, 39-49

${ }^{19}$ Patrice.s.Lee. (2014) Human Sex Differences. Washington, D.C.USA

${ }^{20}$ www.mesbahyazdi.org/english

${ }^{21}$ http://e45o5.hosts.cx/downloads/MesbahYazdi/philosophy\%20instructions, 1 998, p.221.pdf

${ }^{22}$ Ancient Theories of Soul, Stanford Encyclopedia of Philosophy, 2009

${ }^{23} \mathrm{http}: / /$ www.iranicaonline.org/articles/molla-sadra-sirazi

${ }^{24}$ Avicenna, The Book of Salvation, 184

${ }^{25}$ International Journal of Women's Research, 3(1), Spring \& Summer 2014

${ }^{26}$ Fausto-Sterling, Anne "Of Gender and Genitals", New York, NY: Basic Books, 2000, 44-77.

${ }^{27}$ Richard Munna, The Power of Gender. Pearson/Longman. 2003, 221.

${ }^{28} \mathrm{https}: / /$ global.oup.com/academic/product/the-biopolitics-of-gender9780190256913? cc=fi\&lang

29 Virginia Prince. "Sex vs. Gender." International Journal of Transgenderism 8, no. 4 (2005), 29-32. doi:10.1300/j485v08n04_05.

${ }^{30}$ Paul. Richardson, The Nature of Gender, New York: NY New Publishers, 2000.

${ }^{31}$ Zouk Tersan, Gay and Lesbian Alliance. USA, 2011. Germany,

${ }^{32}$ Rosa, Venice. "The New Ideology of Intersex" The Gay \& Lesbian Review. 2012.

${ }^{33}$ Willson Parker. Evolution of Sex and Homosexuality. Monterey: Brooks Cole. 2005.

${ }^{34}$ Carl Tylor, Experiences of the Soul, University of New York, New York, 2015.

${ }^{35}$ Visconsin Flores, D. Nature vs. Nurture. New Mexico. US. 2000.

${ }^{36}$ Davis, Heath F. Beyond Trans: Does Gender Matter?. New York: NYU Press, 2017.

${ }^{37}$ TV serial "Billions" https://www.showtime.com/

${ }^{38}$ Rudolf Steiner, Occult Science, Steiner Books Incorporated, Barns \& Nobel: New York. 2010. 